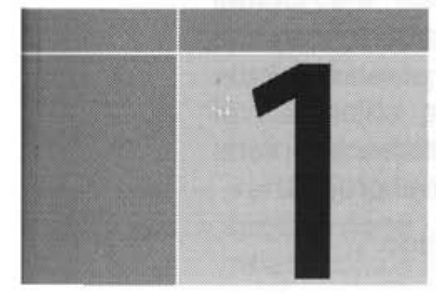

\title{
A Preliminary Study on Human Resource Management in International Construction
}

Jianjian Du, Chunlu Liu and David Picken (School of Architecture and Building, Deakin University, Geelong, Australia)

\begin{abstract}
As construction companies continue to explore foreign construction markets, various international construction projects are being undertaken in all corners of the world. In an international construction project with many unique and complicated characteristics, human resource management can play a significant role in promoting the efficient use of complex human resources. The aim of this paper is to establish a valid foundation for further research on measuring the impact of human resource management economically for international construction projects. The paper examines human resource management literature and identifies the application of the related management techniques to the construction industry. In addition, the paper uses the literature analysis to describe the nature of human resource management with particular reference to international construction projects. In particular, the research described in this paper identifies economic performance factors in the implementation human resource management in international construction projects. This paper also identifies the social effects of human resource management practices.
\end{abstract}

Keywords: Human resource management, construction

\section{INTRODUCTION}

Human resource management (HRM) is concerned with managing people within the employer-employee relationship. Specifically, it involves the performance of people in achieving the organization's objectives and the satisfaction of personal employee needs. HRM can be a major contributor to the success of the enterprise. $\mathrm{HRM}$ has been regarded in various industries as one of the most critical elements of business success. The successful implementation of HRM functions are elements for improving personal, team and organizational performance (Dainty et al., 2000; $\mathrm{Ng}$ et al., 2001; Belout and Gauvreau, 2004). A number of authors state that the basic functions of HRM include planning, job design devising position descriptions, employee selection/recruitment, employee training, performance appraisal systems, reward systems, employee relationships and employee's health and safety (Druker et al., 1996; Maloney, 1997; Bratton and Gold, 1999; Koch, 2003; Loosemore et al., 2003; Ramlall, 2003). HRM substantially influences the output of business, for example, on quality, technology, competitive strategy and development. Furthermore, HRM should include practices, which provide training and development opportunities for all employees to improve individual skills and flexibility of roles (Mullins, 1999).

Human resource management has a significant influence in the construction industry. Although construction technologies and management techniques have advanced rapidly, project managers still need to pay more attention to people management. Human resources still account for the majority of costs in most construction projects (Loosemore et al., 2003). International construction projects normally require a longer time span and more parties are involved (Chan and Tse, 2003). HR issues have positive and adverse implications for construction industries in all countries (Ofori, 2003). HRM is also a significant aspect of the whole planning and project management process in construction projects, in particular international construction projects that involve foreign firms as collaborators or competitors (Bon and Crosthwaite, 2000; Mawhinney, 2001). The complex international construction climate, caused by increased global price competitiveness, development of technologies, changing industry and employment legislation, and changing workforce composition has prompted project managers to utilise their employees more effectively to gain competitive advantage and project success. In recent years there has been a widespread realisation that improvement of HRM performance is a critical element to achieving improvement in efficiency, productivity and cost effectiveness in the construction industry. Howes and Tah (2003) describe how the situational model of HRM, the staff performance model of HRM and the sociotechnical model of HRM are being implemented 
in construction. As a growing number of construction companies are attempting to develop foreign construction markets, large numbers of international construction projects are being undertaken around the world. Due to the complex characteristics of international construction projects, there is an increasing need is to understand the relationships between various project participants and the strategies of HRM, and to develop an efficient HRM approach for an international construction project.

The aim of this paper is to establish a valid foundation for further research on measuring the impact of human resource management economically for international construction projects. In the following section, the paper examines HRM literature and identifies the application of these management techniques and then uses the literature analysis to describe the nature of HRM with particular reference to international construction projects. Then, characteristics of HRM are pointed out by comparing them with traditional personnel management in Section 3. In international construction projects, the influences and relationships will be introduced between all project participants and HRM. Interestingly, some of the HRM characteristics and strategies are quite different at the company level and the project level in construction. Section 4 presents the economic performances in which the HRM process affects project participants in an international construction project. In particular, the added values, costs and benefits of HRM are identified and analysed in the context of construction project implementation. This paper provides the basis for promoting the efficient use of complex human resources involved in international construction projects with unique and complicated characteristics. Finally, conclusions are presented in the fifth Section.

\section{HRM IN INTERNATIONAL CONSTRUCTION}

HRM can play an important role in the process of project management. Although HRM continues to operate with the most basic of personnel functions, which differ little from the traditional practices of personnel management, HRM has qualitatively developed in its strategies. HRM in construction has typically been an emergent rather than a strategic or deliberative process and the construction industry has not been as diligent in implementing HRM as other industries (Brandenburg et al., 2006). International construction projects are one of the activities of this industry, which involve multinational participants from different political, legal, economic and cultural backgrounds. HRM has the potential to be of critical importance in the international construction project for the way in which various employees, despite the casual nature of employment, are benefited from the process of the project. HRM can also contribute to success in achieving the main objectives of attaining target dates, meeting financial plans and controlling the quality of the final project.

\section{HRM for international collaboration}

With the globalisation of economics, culture, politics and techniques, international construction is becoming an important branch in construction management. The environment of an international construction project is far more complex than that of domestic projects and its HRM strategies challenge the project managers as well as the enterprise leaders. Construction contractors involved in international projects should respond to the diversity of environment required for the HRM strategies. If the principal employers of international construction projects are to avoid losing their best staff to their competitors, they must develop more effective ways of rewarding and developing their workforces and meet individual employee career needs and expectations; not just in terms of formal employment contracts but also in terms of their employees' informal expectations of the relationship between themselves and their employer (Dainty et al., 2000).

HRM not only serves and supports the management goals and dynamic changes of international construction projects but also directly influences them. HRM is more suited to the complex requirements of economic activities within international construction projects than traditional personnel management techniques because HRM strategies can better reflect the entire project strategies. For instance, human resource managers of an international project need to introduce HRM strategies and practices to suit the specific interests of a client and the characteristics of a unique project. The casual nature of employment in international construction projects makes the planning of human asset requirements an extremely vague exercise, which can result in low productivity, high employee turnover rates and reduced motivation to train and plan for the long future ( $\mathrm{Ng}$ et al., 2001). As the human resource management priorities may differ in various countries, another challenge is in taking account of the effects of cultural differences in the context of the international applicability of common HRM strategies.

\section{HRM at the project level}

Construction is a project based industry which involves all project participants such as clients, designers, contractors, constructors, and consultants. Most project participants have a 
short-term relationship of cooperation during the project period. Often they can be from different cultural backgrounds, and also possess different construction professional and skill levels. Due to the characteristics of construction projects and various project participants, an increasingly urgent need is to implement HRM to manage relationships among project participants, improve team performance and promote value for individuals in construction projects. Human resource managers need to consider multicultural factors when they constitute and implement HRM strategies and practices at the project level.

At each level there is a significant difference in the strategic goals of HRM. At the company level HRM strategies should ensure that the company's human resource requirements for the long term are met both in terms of numbers and categories of employee (Cole, 2002). In the construction industry, a company needs project managers to make HRM decisions at the project level (Loosemore et al., 2003). Therefore, project managers need to depend on the natural characteristics of projects to establish a specific strategy that is suitable for the needs of employees at the project level. The particular human resource strategies for a project need to focus on short-term human resource requirements to accomplish a construction project successfully.

There is also a difference in training between HRM at the two levels. Training is one of the most important sections in HRM functions. At the company level, the training plans should provide effective training and development opportunities for all employees to enhance personal skills and multi-skill capability. Many companies including construction companies make expensive investments in long-term training plans for developing their employees, which is proven to be worthwhile for company development (Ramlall, 2003). Project managers attempt to provide systematic training for their employees' personal development, but the duration of, and resource stress in, a project, and the routine and daily issues of projccts restrict the extensive implementation of training. It is not really feasible to provide long-term training for employees at the project level. Generally, very simple training such as understanding international construction regulations is provided for project participants. At the project level, the primary responsibility is, largely, to take the existing skill and knowledge level and manage their existing human resources to achieve the maximal performance. However, HRM at the company level focuses on development of employees' potential, not necessarily with particular projects in mind, but which can improve the performance in the longterm period.

It is generally agreed that international construction projects possess a variety of human behavioural variables in addition to the conventional technical variables in budget, schedule and quality (Han and Diekmann, 2001; Belout and Gauvreau, 2004). With respect to success, historically, construction projects have been managed in terms of technical perspectives, including cost, time and quality. International construction projects involve not only technical challenges common to domestic construction projects, but also the complex and interrelated behavioural difficulties particular to international projects. Human resource management applied to international construction is not a revolutionary strategy in itself, but the concept and elements of human resource management approaches may serve as building blocks for developing the workforce management strategies for complex and extensive international construction projects.

\section{HRM IMPLEMENTATION STRATEGIES IN INTERNATIONAL CONSTRUCTION}

Practically, the usual requirement is for business strategy to be translated into human resource practices. HRM plays an active role in this process. Human resource managers need to develop human resource strategies based on the defined business strategies. As a consequence, a human resource strategy directly influences the success of a business. In construction, effective and efficient HRM strategies positively affect costs, schedule and quality at the project level.

\section{Critical factors influencing HRM implementation}

With the rapid growth of globalization, HRM implemented in the construction industry needs to develop its strategies and practices to suit international construction projects. Therefore, it is very important to understand the differences between HRM in general international businesses and in international construction. HRM in international construction has some particular characteristics, as distinct from HRM in other international businesses such as in the aviation industry and international trade, or HRM in domestic construction. Those characteristics are the embodiment of general and unique influence factors for HRM in an international construction project.

Generally, international construction projects involve more complex relations between the various project participants, project profiles and special labour requirements when compared to domestic construction projects (Liu et al., 2003). 


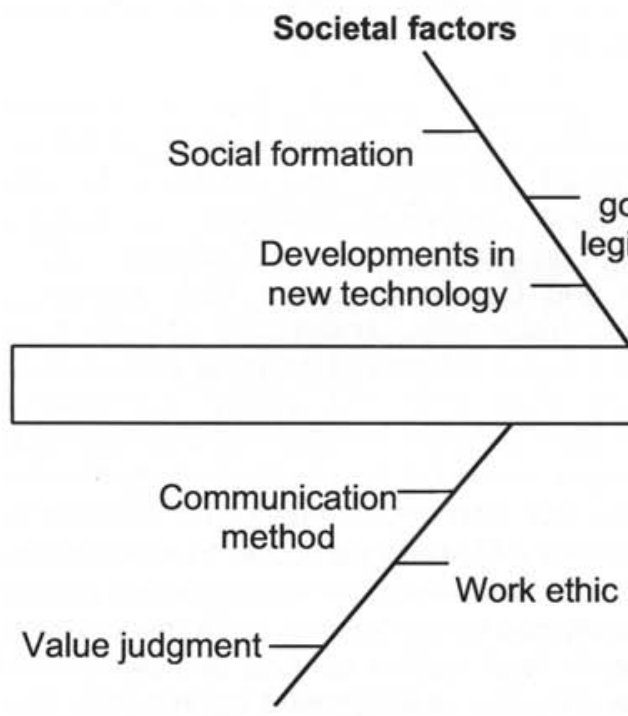

Culture factors

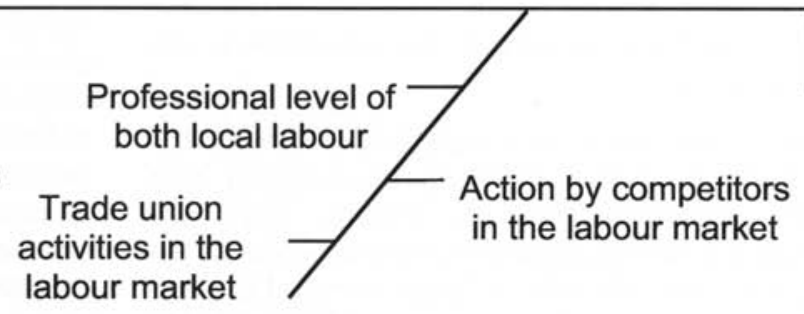

Workforce factors

\section{Figure 1: Unique factors affecting HRM implementation in international construction}

First of all, typically project participants are from different cultural backgrounds, which are reflected in the way that people are managed, how people are evaluated, how people are hired, and in particular, how people are promoted (Loosemore, 1999). It is generally acknowledged that the contextual environment of a country also influences the construction industry of each jurisdiction (Chan and Tse, 2003). Therefore, HRM strategy that is implemented in an international construction project needs to be based on the cultural backgrounds of project participants. As a result, HRM strategy in an international project needs to satisfy multicultural needs. Human resource managers need to spend a relatively long time to improve communication among project participants. This includes enhancing the understanding of different work methods, work ethics and technical level among all project participants. A model of HRM which involves multicultural needs within projects can help project managers to develop favourable employee relations among all project participants in international construction projects.

Another main factor that affects HRM strategies is the duration of a construction project. According to the duration of construction projects, HRM needs to make its strategies based on short-term objectives. For example, employee training is varied between international construction projects and other international businesses. For international business in general, employee training needs a highly systematic plan to develop employees' potential and improve their skills to fulfil long-term business objectives. On the other hand, human resource managers do not have time to provide long-term training planning to enhance employees' skills and performance at the project level. To maintain the interests of both clients and contractors, the foremost responsibility of human resource managers is to manage the current employees to contribute their maximum value and performances in international construction projects. In addition, most employees on an international construction project are often involved only for a short term. Human resource managers therefore need to increase the level of employees' loyalty through some special strategies and practices such as high reward systems, systematic employee welfare support and equitable performance appraisal systems.

Furthermore, the unique factors of an international construction project create more substantial influences on the implementation of HRM. For example, Kim (1999) and Milliman et al. (2002) state that the implementation of successful global strategies needs to pay more attention to the cultural differences in the HRM. The factors influencing the implementation of HRM in international construction can be identified and classified in various manners (Liu et al., 2003). Indicating these factors is important for all participants of an international project. Figure 1 presents an approach to formulating critical factors in detail, which hierarchically affect HRM in international construction projects. The factors presented here include international and local labour markets, economic conditions, 
cultural factors and societal factors and can be extended with the future practice of HRM in international construction.

Societal factors include development of new technologies, local government legislations and policies and social formation. The planning and implementation of employee training are affected significantly by the development of the new technologies. Engineering and management concepts, theories and technologies that the project participants have acquired may differ each other because of the variety of their backgrounds. Social factors such as language barriers also contribute to difficulties in the HRM implementation in international construction. Whilst scientific methods and engineering technology are readily transferable, it is the human factor which makes for social differences. The history and mode of society, the customs and traditions, work habits, personal or community attitudes and philosophy which makes for differences in efficiency, effectiveness of performance and ultimate success or failure of an international construction project. Ignorance or neglect of social determinants in international construction could well mean failure, frustration and disappointment, but recognition of such factors, adequate investigation of and preparation for overcoming the problems associated with them will ensure successful international construction management.

Cultural diversity is one of the most important factors that affects and impacts on strategies and practices of HRM. In particular, training planning, reward systems, performance appraisal, leadership and employee relations in an international construction project need to be adjusted or optimised according to diverse cultural backgrounds of its participants such as their varied work ethic and value judgments. Because of the differences in the cultures of countries, there exists various kinds of differences in their construction markets. These differences highly affect the tender and bidding methods for construction projects, and decision making. Although times may be changing, it is essential for an international construction enterprise to adjust itself for each individual country. Understanding the market mechanics of a country is fundamental for market entry and the success of a construction enterprise in an overseas market is to some extent dependent on the investigation of the influence of local culture onto the construction market. Communication is also a key issue for project participants because of the different languages and the methods of communication.

Another important factor concerns the economic effects which can flow from HRM implementation.
For instance, changes in exchange rates under floating conditions can have drastic impacts on the success of the projects as one objective of the constitution and implementation of HRM strategies is for a project to be an economic success. International and local economics also affect both the planning and implementation of HRM strategies and practices because they directly influence the project's success.

In international and local markets, an uneven professional level of labour can directly affect the benchmarks of employee selection. Moreover, job design, reward systems, and performance appraisal are impacted strongly by activities of competitors and trade unions in the labour market because those activities can provide more opportunities for job applicants. As a consequence, an international construction company faces great competition in the labour market. Given the increasingly competitive nature of the labour market, the recruitment and retention of employees, in particular professional and managerial employees, challenges the managers of the project. For example, construction managers normally acquire knowledge and skills in construction methods and management techniques on the basis of long-term practice, and turnover in this level of employee can significantly impact on the survival and development of any international construction project and cause poor performance, low competitiveness and high technology loss.

Governments have a large influence on the implementation and management of international construction projects. A government's influence can directly take place through tariffs on imports into a country and through various taxes that may be imposed on foreigners operating within countries, especially when they look to repatriate profit derived from these foreign nations to their home countries. Furthermore, there is no doubt that there exists some special treatment accorded to the domestic contractors in the construction markets of some countries, and the use of the construction sector by the government to soak up excess capacity is a form of feather bedding that may better allow these contractors to operate on a quite different basis internationally than their competitors from other countries. Another major way governments can affect international construction projects is how they follow up the agreements of international organizations such as the World Trade Organisation, the General Agreement on Trade and Services and so on. As all governments seek to look after their own interests and inhabitants, there may not exist a true global market with no barriers to trade. It is some way 
off before a relatively fair market can be built worldwide for international construction projects.

\section{HRM functions of project participants}

In an international construction project, there are the mutual influences between various project participants and strategies of HRM. Therefore, it is necessary to understand the responsibility and function of all project participants for HRM in an international construction project. The main project participants include the client, contractor, project manager, consultants and government in a construction project. They all play an important role in project management process and HRM. Some of them have a significant impact on the strategies of HRM, and some of them are important elements in some discrete practices of HRM.

Clients are usually defined as investors in projects. They are original owners of construction projects. The construction project's objectives and functions are devised by clients. Therefore, a client's interests and objectives can indirectly affect decision making in HRM strategies. For instance, human resource managers should make HRM strategies in light of a project's requirements and objectives that clients expected on HRM in the early stage of construction project such as in the HRM planning stage. Clients can also give some suggestions to human resource managers (e.g. contractors or project managers) to constitute particular human resource strategies at the project level. These HRM strategies should be directly helpful in achieving success in construction projects.

Naturally, contractors play an important role in HRM in international construction. The responsibilities of contractors include four major parts. Firstly, contractors need to discuss with clients to adjust the objectives of construction projects. The adjustment is able to ensure the reasonable and accurate objective of projects that impact strongly on HRM in construction projects. Secondly, the contractor is one of those involved in HRM planning. Contractors need to transfer the client's interests to project managers, and both of them develop a particular HRM plan based on the client's interests and the objectives of a construction project. Thirdly, contractors need to participate in devising position descriptions. They should make a set of complete position descriptions with the project managers. Lastly, the contractor has an important role in recruitment. They need to help the project managers to select and recruit the most suitable employees.

Project managers play a human resource management role in a construction project. In an international construction project, project managers are made up of local project managers and overseas project managers. The local project managers are from the location of the international construction project. They should have complete comprehension of the local professional levels in construction, construction regulations and government polices. The local project managers can help clients and contractors to make a set of HRM strategies that are suitable for the characteristics of projects. The overseas project managers are from other countries. Usually they are knowledgeable in advanced methods of construction management and construction technologies. They can play an important role in HRM during the implementation of training.

Consultants can play a role in promoting construction technologies at the project level. For instance, consultants who possess knowledge in advanced construction techniques such as construction engineers can facilitate training of employees in some international construction projects. The professional skills and knowledge of consultants in architecture, engineering or management make significant contributions to the implementation of HRM in a specific project such as training, benchmarks of performance appraisal and reward systems.

Each project participant plays a different role in HRM over the period of an international construction project from its decision making to completion. Based on current practice in international construction, the key functions of each project participant are summarised in Figure 2. The time framework comprises planning, pre-implementation and implementation stages.

In the planning stage, due to cultural factors, HRM strategy planning and position descriptions are quite different in an international construction project when compared to a domestic construction project. For example, a construction engineer and a construction inspector can be one person in a construction project in some countries due to different construction systems and regulations. Hence, in such countries the duties of the two professions need to be included in a position description. The local project managers who understand the local construction regulations, environment and labour market play very important roles in implementation of HRM over the whole project process. The local project managers will directly participate in the establishment of HRM planning and job design with contractors. Employee selection and recruitment should be conducted by local project managers and contractors. 


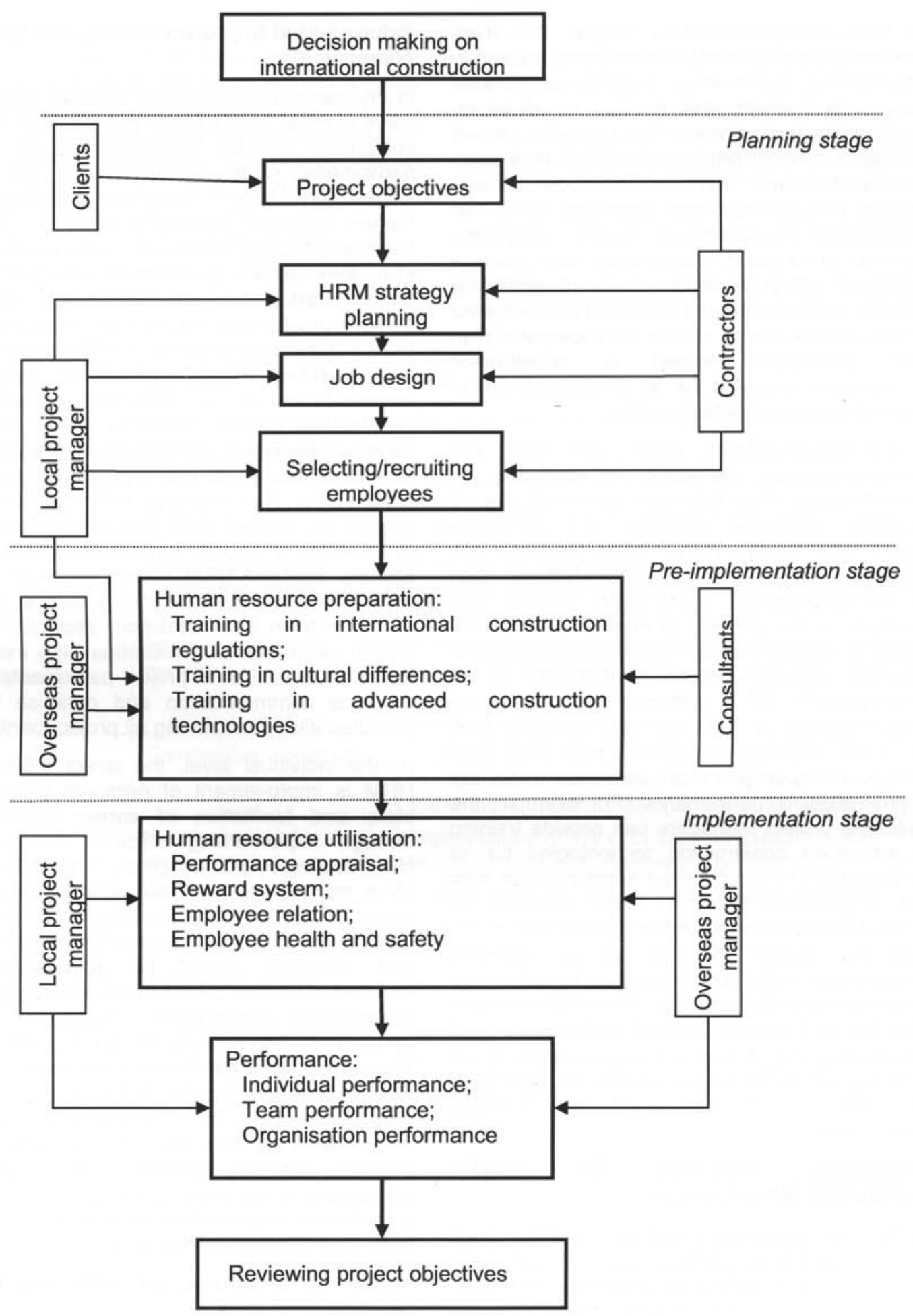

Figure 2: HRM functions of project participants 
In the pre-implementation stage, the main practice is employee training including training in international construction regulations, cultural awareness training and training in advanced construction technologies. The overseas project managers whose professions have been well developed in their home countries can have a positive role in improving employee skills and construction technologies during employee training. In addition, consultants can have a significant influence in the stage of employee training. For instance, the professional skill level of consultants directly affects the capacity to plan and implement training in construction technologies provided for all employees on an international construction project.

In the implementation stage, both local and overseas project managers will also play an important role in performance appraisal, reward systems, employee relations and employee health and safety. These HRM practices are affected strongly by multicultural characteristics in an international construction project. For example, in the process of managing employee relations, project managers need to consider the different cultural customs and habits of al employees. In addition, the whole implementation of HRM improves the individual, team and organisation performance. Both local and overseas project managers also affect the improvement of performance. For example, the overseas project managers can provide training in advanced construction technologies for all employees. The local project managers can help the employees who are from overseas to understand local construction regulations. In the end, the project objective will be reviewed because the HRM strategies can influence the adjustments of the projects. The HRM functions identified in this paper support and serve project objectives, and ensure project success in an international construction project by specifying the HRM roles and interrelationships of project participants.

\section{ECONOMIC ANALYSIS OF HUMAN RESOURCE MANAGEMENT}

HRM is an expensive investment and the direct affect on profits for each company, project team and individual is difficult to determine. However, HRM indirectly adds values and enhances benefits for every company, project team and individual. It is necessary to analyse the economic performance of implementing HRM. In an international construction project, the values added, the costs and benefits of HRM to project participants and their companies are the most important benchmarks of economic analysis.
Values added to project participants and their companies

In international construction projects, the added value of HRM is situated at the strategic level for companies and the individual level for project participants. At the strategic level, the added values of HRM are in three main domains. Firstly human resource managers need to translate business strategy into human resource practices in an international construction project. Thus, all project participants can develop their ability to achieve project success through HRM practices. During the implementation of HRM practices, all project participants can understand clearly their responsibility in a particular international construction project. Secondly, HRM needs to balance between an expected outcome of project success and the capacity of all project participants. The expected outcome cannot be beyond the abilities of all project participants and in addition, it cannot be set lower than their abilities. Efficient HRM should direct all project participants to contribute their maximal value in an international construction project. Thirdly, unified personnel administration also increases the added value for all project participants. It can enhance communication and optimise human resource allocation among all project participants.

At the individual level, the direct influence of HRM is improvement of personal professional skills and facilitation of career development through implementing efficient and effective HRM strategies and practices. This influence is often more explicit in international construction projects than in other construction projects. All employees who are from different companies and countries should be able to acquire knowledge in new construction technologies and international construction regulations through employee training during the duration of projects. They also add to the international aspect of their work experience records. Furthermore, HRM not only adds values for individual employees but also creates the value for their companies. HRM promotes indirectly competitive advantage of the companies of all project participants. HRM can also deliver values within different areas, ranging from the individual to the company.

\section{Modelling structures of HRM costs and benefits}

An increasing trend is that a substantial amount of money is being spent in HRM in various industries including the construction industry. Given this significant investment, it is reasonable to enquire about the benefits of such investment. An analysis of costs and benefits is an important benchmark in evaluating HRM (Ramlall, 2003). 
In an international construction project, the costs of HRM are made up of major costs and minor costs. Table 1 shows the major and minor costs of HRM in international construction project. The major costs of HRM include costs of personnel administration, employee training, costs of communication, employee welfare and compensation of health and safety.

Employee training and personnel administration are two major sources of HRM costs. The American Society for Training and Development estimates that organisations in the USA are spending more than US\$ 60 billion annually on employee training (Ramlall, 2003). With multicultural project participants and different levels of professionals in an international construction project, human resource managers need to provide the particular training that meets the needs of multicultural participants and the different professional levels. In addition, complex training planning needs to expend more investment in an international construction project than in a domestic construction project.

\begin{tabular}{|c|c|c|}
\hline Objectives & Benefits & Descriptions \\
\hline \multirow{2}{*}{$\begin{array}{l}\text { Individual } \\
\text { project } \\
\text { participants }\end{array}$} & $\begin{array}{l}\text { Personal skills and } \\
\text { career development }\end{array}$ & For example, acquire new professional technology \\
\hline & $\begin{array}{l}\text { Flexibility of personal } \\
\text { role }\end{array}$ & $\begin{array}{l}\text { Individual project participants can be competent in } \\
\text { various positions in an international construction } \\
\text { project. }\end{array}$ \\
\hline \multirow[b]{2}{*}{$\begin{array}{l}\text { Non-individual } \\
\text { project } \\
\text { participants }\end{array}$} & $\begin{array}{l}\text { Better relationships } \\
\text { among the team }\end{array}$ & $\begin{array}{l}\text { An important responsibility of human resource } \\
\text { management is to improve relationships among } \\
\text { employees in the team. }\end{array}$ \\
\hline & $\begin{array}{l}\text { Improving team } \\
\text { performance }\end{array}$ & $\begin{array}{l}\text { Human resource management can improve team } \\
\text { performance through various practices such as } \\
\text { improvement of individual skills in the team, in } \\
\text { relations and leadership. }\end{array}$ \\
\hline \multirow{5}{*}{$\begin{array}{l}\text { All project } \\
\text { participants' } \\
\text { companies }\end{array}$} & Competitive advantage & $\begin{array}{l}\text { Due to improvement of each employee's skills by } \\
\text { human resource management, it is certain to improve } \\
\text { the whole company's competitive advantages. }\end{array}$ \\
\hline & $\begin{array}{l}\text { Improvement of } \\
\text { productivity }\end{array}$ & $\begin{array}{l}\text { Improvement of the individual performance can } \\
\text { enhance the whole company's performance. }\end{array}$ \\
\hline & $\begin{array}{l}\text { Improvement of } \\
\text { organisational } \\
\text { performance }\end{array}$ & $\begin{array}{l}\text { Cooperation of individuals who possess knowledge in } \\
\text { new technologies can certainly improve overall } \\
\text { productivity. }\end{array}$ \\
\hline & Business success & $\begin{array}{l}\text { Human resource management strategies are not only } \\
\text { close to business strategies but also support and } \\
\text { serve business objectives. }\end{array}$ \\
\hline & Employee benefits & $\begin{array}{l}\text { To enhance employee loyalty in the company. For } \\
\text { example, through salary and welfare benefit levels. }\end{array}$ \\
\hline
\end{tabular}




\section{DISCUSSION AND CONCLUSIONS}

Globalisation of construction markets has allowed more individuals and companies in the construction industry to collaborate or compete internationally. The complexities and interrelationships in an international construction project require that its key players possess comprehensive knowledge in implementing HRM. Human resource management is qualitatively different from traditional personnel management. HRM strategies and practices are developed and implemented in the light of business objectives needs. HRM is a major requirement for all project participants in an international construction project because traditional personnel management is not satisfactory due to the complex personnel structure in international projects. Human resource management, as a successor to personnel management, is more suitable for dealing with personnel issues in multicultural environments. However, a variety of factors influence the implementation of HRM in international construction. The economic performance associated with HRM implementation is also worthy of elaborate investigations for each of the project participants.

This paper has reviewed previous research on human resource management in international construction and indicated the unit features of HRM for international collaboration and at the project level. The research presented in this paper has summarized the key factors of HRM implementation in international construction and the HRM function of each of project participants over the project period. This paper originally presented the economic performances of HRM implementation in an international construction project, including its added value, costs and benefits. This paper has established a valid foundation for further research on measuring the impact of human resource management economically for international construction projects. For future extension of this research, numerical analyses based on empirical data will focus on quantitative studies of each HRM component relevant to international construction projects.

\section{References}

Belout, A. and Gauvreau, C. (2004). Factors influence project success: the impact of human resource management, International Journal of Project Management, 22(1), 1-11.

Bon, R. and Crosthwaite, D. (2000). The Future of International Construction, Thomas Telford, London.
Brandenburg, S., Haas, C. and Byrom, K. (2006). Strategic management of human resources in construction, Journal of Management in Engineering, 22(2), 89-96.

Bratton, J. and Gold, J. (1999). Human Resource Management Theory and Practice, Macmillan Press, London.

Chan, E. and Tse, R. (2003). Cultural Consideration in International Construction Contracts, Journal of Construction Engineering and Management, 129(4), 375-381.

Cole, G. (2002). Personnel and Human Resource Management, Continuum, London.

Dainty, A., Bagilhole, B. and Neale, R. (2000). The compatibility of construction companies' human resource development policies with employee career expectations, Engineering Construction and Architectural Management, 7(2), 169-178.

Druker, J., White, G., Hegewisch, A. and Mayne, L. (1996). Between hard and soft HRM human resource management in the construction industry, Construction Management and Economics, 14(5), 405-416.

Han, S. and Diekmann, J. (2001). Approaches for making risk-based go/no-go decision for international projects, Journal of Construction Engineering and Management, 127(4), 300308.

Howes, R. and Tah, J. (2003). Strategic Management Applied to International Construction, Thomas Telford Publishing, London.

Kim, P. (1999). Globalization of human resource management: a cross-cultural perspective for the public sector, Public Personnel Management, 28(2), 227-243.

Koch, C. (2003). Knowledge management in consulting engineering - joining IT and human resources to support the production of knowledge, Engineering, Construction and Architectural Management, 10(6), 391-401.

Liu, C., Xu, Y., Itoh, Y. and Tian, J. (2003). Critical Operational Management in International Construction, Proceedings of Joint International Symposium of CIB Working Commissions, Singapore, Singapore, 379-387.

Loosemore, M. (1999). International construction management research: cultural sensitivity in methodological design, Construction Management and Economics, 17(5), 553-561. 
Loosemore, M., Dainty, A. and Lingard, $\mathrm{H}$. (2003). Human Resource Management in Construction Projects, Spon Press, London.

Mawhinney, M. (2001). International Construction, Blackwell Science, Oxford.

Maloney, W. (1997). Strategic planning for human resource management in construction, Journal of Management in Engineering, 13(3), 49-56.

Milliman, J., Taylor, S. and Czaplewski, A. (2002). Cross-cultural performance feedback in multinational enterprises: opportunity for organizational learning, Human Resource Planning, 25(3), 29-43.

Mullins, L. (1999). Management and Organisational Behaviour, Pearson Education Limited, Essex.

Ng, S., Skitmore, R. and Sharma, T. (2001). Towards a human resource information system for Australia construction companies, Engineering, Construction and Architectural Management, 8(4), 238-249.

Ofori, G. (2003). Frameworks for analysing international construction, Construction Management and Economics, 21(4), 379-391.

Ramlall, S. J. (2003). Measuring human resource management's effectiveness in improving performance, Human Resource Planning, 26(1), 51-62. 